Government scheme for promoting industry on scientifie lines. Morgan inspired a large number of students, a high proportion of whom went into industry; and he turned his attention continually to now fields of investigation, showing remarkable versatility. Diazo reactions of aromatic diamines; organic compounds of phosphorus, arsenic and antimony; high-pressiure reactions; base exchange materials; synthetic resins; low-temperature tars, were only a few phases of his activities. Few men have done more than Morgan to carry the torch kindled by Hofmann along the highways of England, and to take chemical knowledge and scientific method into the lives of many as teacher, colleague and friend.

M. O. Forster likewise started at Finsbury, then went to Würzburg, where he took his degree and came back to the Central as Salters' Company Research Fellow. He came to the Royal College as demonstrator in 1895, being promoted assistant professor in 1902, a post he held until 1913. Forster carried out a brilliant series of organic researches from the College and was an inspiring influence there. He went to British Dyes during a troubled period, was later first director of the Salters' Company's Institute of Industrial Chemistry and four years later went to Bangalore as director of the Indian Institute of Science, where he did outstanding work for Indian science.

J. C. Philip, an Aberdonian and a pupil of Japp, studied under Nernst in Göttingen, and after a year with H. E. Armstrong at the Central gave a course of lectures in physical chemistry at the Royal College at the invitation of Tilden; he became lecturer there in 1900, assistant professor when Thorpe returned to the chair in 1909, and professor of physical chemistry, a new appointment, in 1913. From then until his death in 1941, Philip was responsible for this allimportant subject. He was a teacher of great ability, and did much to establish a school of research in physical chemistry in the College during a period of very rapid growth of this branch of science.

J. F. Thorpe was a student of the Royal College in 1892-93, but developed largely under the influence of Auwers in Heidelberg and of W. H. Perkin, jun., at Manchester. He came back to the College when the chair of organic chemistry was created there in 1913, and there attracted and inspired a following of staff and research students in part because of his remarkably neat and effective technique. Under his leadership, research in organic chemistry flourished in spite of the interruption caused by the First World War. J. F. Thorpe later devoted the greater part of his time to administrative work and to Government committees, but the school continued to flourish under his assistants, among whom were included Ingold, Linstead, Farmer and Kon.

The College has played its part also in the provision of standard chemical literature without which the progress of research would be greatly hampered. The famous "Thorpe's Dictionary of Applied Chemistry" was first published in 1890 in three volumes : in its compilation, Sir Edward Thorpe had the assistance of many of the College staff besides outside collaborators. A second edition in five volumes began to appear in 1912, and a third in 1921. The First World War emphasized the value of the work and the need for a further revision. This was undertaken by J. F. Thorpe and M. A. Whiteley, thus maintaining the association of the "Dictionary" with the chemistry staff at South Kensington. It has become clear that pure science and technology cannot be divorced in a dictionary, so that the fourth edition of "Thorpe" now in progress is much wider in scope. Begun by Sir Jocelyn Thorpe and Dr. Martha A. Whiteley, it is being continued by a board of editors of which Prof. I. M. Heilbron is chairman, Dr. H. J. Emeléus a member, with Dr. Whiteley as editor and Dr. A. J. E. Welch as assistant editor.

Chemists are not unmindful of the important services rendered by A. J. Greenaway (1871-8I) as sub-editor of the Journal and Abstracts of the Chemical Society over a period of forty years.

Examination of the "Register of Old Students of the Royal College of Seience" confirms the impression that, in the closing years of last century, associates in chemistry found employment more easily in teaching than in industry. 'The title 'Normal School' was, rightly or wrongly, regarded as favouring this preference, owing to connotation with the French Ecole normale, although the methodology and discipline of pedagogy never formed part of the curriculum. But this preference for teaching posts need not be ascribed to predilection, as chemical industry offered relatively few openings and these none too well remunerated, with little or no assurance of security of tenure. But with the awakening of Britain to the growing need of scientific training and aptitude in industry, an improvement in prospects set in, which quickened with the growth of the present century. With the outbreak of the First World War, widespread deficiencies were revealed, and the supreme importance of research in so fundamental a subject as applied. chemistry, woing to its manifold aspects in connexion with explosives, coal, oil, metallurgy, pharmaceuticals, plastics, fabrics, food products, etc., could no longer escape recognition. Then followed the establishment of the Department of Scientific and Industrial Research, with its research associations of manufacturers, and to-day cogent evidence of the imperative need of chemistry is witnessed by urgent advertisements in the daily and technical Press and combing of the Central Register for chemists. In its contribution to the yearly academic output of some four hundred first-class honours graduates in chemistry shortly before the outbreak of the present War, and their absorption in teaching and industry, it may be claimed without fear of contradiction that the College has faithfully fulfilled the purpose of its founders - that of promoting the application of chemistry to the "Arts and Manufactures".

\section{THE ARMY SCHOOL OF EDUCATION, ELTHAM PALACE}

\section{BY MAJOR T. H. HAWKINS}

$\mathrm{A}$ NOTHER chapter in the development of adult education in Great Britain has been begun with the opening of the new Army School of Education at Eltham Palace in Kent. To those who believe that the main cultural impact on adults is social rather than strictly educational, the choice of this historical setting with its rich associations will give real pleasure.

The Palace dates far back into history. In the time of Alfred there was "a goodly residence amidst these estates" and the dwelling and demesne are mentioned in the Doomsday Book. Edward the Confessor found spiritual calm at Eltham, and the 
abode was of sufficient magnificence to support the whole court of Henry III on various occasions. Edward I and II both lived for a while in this Kentish Palace, and in their time the stewardship was entrusted to Antony Bek, Bishop of Durham, who not only beautified the place, but sited and built the moat and its walls in 1300. Much of this work is extant, as is the original stone bridge built in 1396 by command of Richard II. In the reign of Edward IV the Great Hall, with its superb hammer-beam roof, was built, and since 1479 this building has stood, almost the hub of the realm in the time of Henry VII and Henry VIII, both of whom lived at Eltham, until during the Parliamentary Wars the whole estate was razed, all but the hall itself, the timbered roof and stout walls of which offered shelter to herds of cattle. week. This was to be run by the Army for the Army and in the King's time. The Army Educational Corps was to be responsible for the general administration and supervision of the scheme; but in units the responsibility for organizing the educational work devolved upon commanding officers and unit education officers. The Education Branch at the War Office was charged with providing books, materials and equipment, and with drawing up necessary schedules of accommodation.

With the defeat of Germany it was decided by the Army Council that, in those units where it was possible, this Army Education Scheme should be implemented from July 1, 1945. This was carried out and, since that time, an increasing number of units, both at home and overseas, has inaugurated

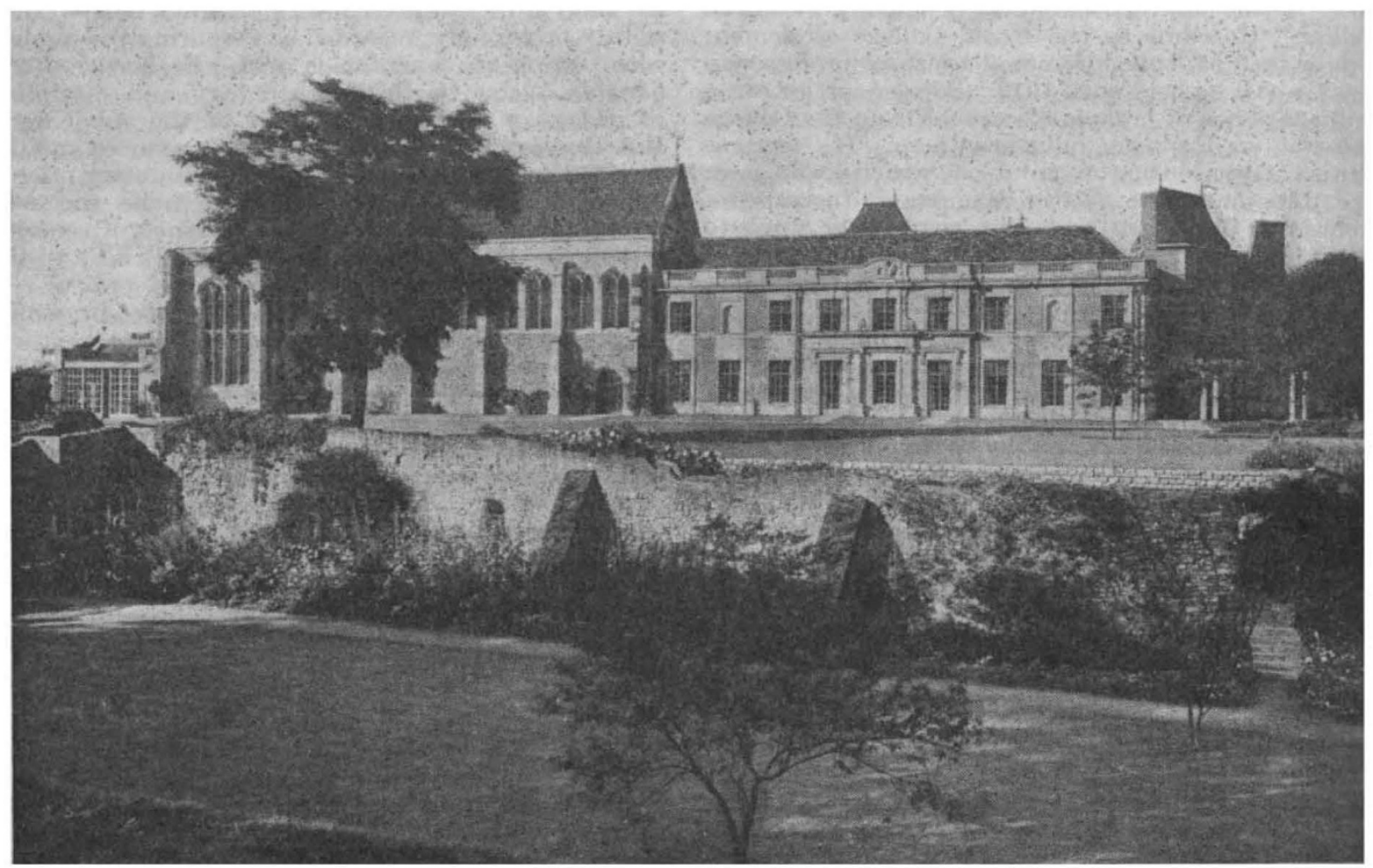

elimam palace. The Great halu and new buimding from across the moat. Copyright Country Life.

Little restitution was effected until 1911, the Hall remaining only a rallying point for historians and painters; but in that year some repairs were made by the Ancient Monuments Department. In 1933 the lease was acquired by the Courtauld family; the Hall was restored, new wings added, and decrepit and extraneous dwellings which had encroached upon the estate were pulled down. About a year ago the lease was generously returned to H.M. the King.

Enough has been said to show that an atmosphere has been provided in which the spirit of education can unfold in the noblest of traditions. But what of the content of the educational programmes that are to be devised and carried out in the new school ? This can be appreciated only by considering the background of the educational work of the Army as a whole. Before the defeat of Germany, arrangements had been made whereby every man and woman in the Army should, as soon as was practicable, be given opportunities to do six hours educational work each extensive educational schemes in their units. A recent estimate, for example, suggests that about 65 per cent of the units in one District in Great Britain is carrying out the Army Education Scheme, in full or in part, as originally propounded. In B.A.O.R., C.M.F. and M.E.F. many difficulties have been encountered in addition to those which have been faced by units at home; but in these theatres, too, the task of providing opportunities for educational activities is being tackled with good results.

This, briefly, is the picture in which the opening of Eltham Palace as an Army School of Education acquires significance. However near to perfection was the gigantic Army Education Scheme as planned by the War Office Education Branch, until it was tried out in practice it could not be anything but a paper scheme. Experience has already shown that in many respects the planned scheme had laid too great emphasis on what the men and women ought to demand and not, in fact, what they have de- 
manded. The original pattern for developing the scheme which had been devised by the War Office has, in many cases, been superseded by arrangements which the units consider to be improvements on any scheme which could emanate from the War Office. In short, the infant which was perfectly conceived some months ago is now going through all the pangs of infancy.

What does the War Office do in such cases? Many observers labour under the belief that any deviation from orthodox War Office programmes on the part of military units is tantamount to quick extinction for the individuals concerned. However much this may be true of some War Office Departments, it is certainly untrue of the Education Branch, and units have been left to develop educational schemes which would best suit their local eonditions. This has led to improvisations and experiments which have enriched the scheme as a whole, and, whenever possible, new ideas and suggestions have been incorporated into the general scheme and made available for the use of other units.

Here lies one of the main purposes of the new Army School of Education. From time to time Army Educational Corps officers are to be brought in for short courses to discuss the practical difficulties which are being met with in the field and whether they are being surmounted and by what means. Most of these officers will be drawn in from home commands, but occasionally they will be joined by officers from overseas theatres, and, lest their discussions tend to concentrate too severely on the supervisory and administrative difficulties, these Army Educational Corps officers are to be joined on various courses either by the unit education officers who are concerned with the fine details of the scheme in the units themselves, or by commanding officers who are responsible for seeing that good educational facilities are being provided for men and women under their command. The interchange of ideas between those who are concerned with running the scheme on the ground and those who have planned and are responsible for the broad principles of the scheme, as well as the general details of administration, should be of great service to the soldiers and auxiliaries who are anxious to make use of the opportunities provided.

Nor can a scheme which aimed to provide educational facilities for at least six hours weekly to some four to five million adults be carried out without a large administrative and organizing staff. About a year ago the Army Educational Corps began to expand rapidly, but even apart from the expected wastages through demobilization, the number of officers in the Army Educational Corps is still very inadequate to carry out effectively their difficult role. The number of candidates who are anxious to transfer to the Corps is fortunately very high, and another of the duties of the new School is to provide courses whereby suitable applicants may be graded and assessed as to their suitability for transfer. This is done by testing their ability in organizing and instructional technique, by their contributions to discussions and the work of the School as a whole, as well as their general demeanour. Again, the interplay of ideas between those transferred and those already experienced in army education in the field should be of considerable value to the new entrants to the Army Educational Corps.

Even then the functions of the School are not exhausted. In some theatres of war, particularly India, some Army Educational Corps personnel have been primarily concerned with the teaching of English to Indians and of Urdu to British personnel, and have had little chance of finding out the tremendous developments in army education during the later years of the War.

These individuals have often been overseas for periods of not less than seven years and, when they come home, feel an urgent need for 'refresher' courses where they might be brought up to date with the latest developments in army education. For these, Eltham Palace also makes provision.

So far, one course only has been held, and its success augurs well for future arrangements. The discussions between those already experienced in army education and who are anxious to share their experiences with similar individuals, those who are keen to become members of a Corps which has won good report during the War, and those whose experiences have been in other directions and who need re-orientating, have already shown the value of such a School and the interest that will accrue to it with each successive course.

One of the sessions, which should be of consider able use to adult education, is that in which officers discuss the Army Education Scheme and its carryover to the national educational system. It is well known that, before the War, the vast majority of the adult population had been unattracted by any of the educational movements which, on the whole, had been providing sustenance only for those already converted. Bound up with this was the fact that most of the classes provided were too academic and paid too little regard to the variety of human interests. Further, there had been an unsatisfactory and unnecessary division between vocational and non-vocational subjects. From the early days of the War, Army educationists had adopted a different policy and, from the beginning, sought to provide educational opportunities not for the few but for the many. Their role as proselytes has taken them up many gum-trees; but the spirit in which the work has boen tackled has led them to attempt experiments and improvisation which have often opened new doors to the education of adults.

The new teehnique which has been most successful is the use of the informal discussion method for stimulating initial interest in what might, to the group, be a new subject. Another is the use of visual aids, and, already, both in direct teaching and in information rooms, the Army has set up a standard of which it is rightly proud. The value of residential education for adults has been argued persuasively by, among others, Sir Richard Livingstone, and there is no need to repeat the advocacy.

In the many hundreds of residential courses which the Army has run, considerable experience has been gained not only in the organization of such courses but also in framing programmes which would be most effective in the short periods available. Other work which has long since passed the experimental stage has been done for patients in hospitals and convalescent homes and for soldiers under sentence in military prisons and detention barracks. So, too, has the remarkable work in basic education which has succeeded in transforming the lives and values of many former illiterates. At present, experiments in the use of educational broadcasts are being made and their progress is being carefully noted.

The discussions on all these topics have been framed so that officers can make concrete suggestions from their own army and civil experience as to the 
most suitable means of transferring these new devices in adult education to the civil education system. Army educationists are well aware that during the War a new interest in adult education has been built up and they are anxious that this interest shall be directed into useful channels before it evaporates; hence the need for careful deliberations before the mass of men and women are demobilized and for quick action afterwards.

The Ministry of Education is fully alive to the need for the immediate capitalizing of this newly gained interest in education by adults, and it is pleasing to report that here, too, Eltham Palace is to play a useful part. At the time of writing, more than a score of His Majesty's Inspectors are attend. ing a short course to learn the main principles of the Army Education Scheme. Very shortly they will go to commands at home and overseas to see how effectively the Army Education Scheme is working on the ground. After a few months of this field work, they will come together again, their recommendations collated and transmitted to the Ministry for any action that is thought desirable.

Eltham Palace has been on the map for some five hundred years. Its significance in history, like good wine, needs no bush. In contemporary affairs it has acquired a new meaning. That lies in the choice of the Palace as an Army School of Education with the elear recognition that worthwhile education deserves a home where it can prosper and flourish.

The Army Council is to be congratulated on securing this magnificent building for what will now become the permanent home of the Army Educational Corps. On October 25 it was officially opened by the Parliamentary Under-Secretary of State for War, Lord Nathan. He was supported by General Sir Ronald Adam, the Adjutant-General to the Forces, and many other distinguished men and women. The first Commandant of the School is Lieut.-Colonel W. S. Beddall.

\section{OBITUARY}

\section{Prof. F. Vejdovský}

Six years ago it was noted in these columns that Prof. F. Vejdovský, the distinguished Czech zoologist, was then about to celebrate his ninetieth birthday (see Nature, 144, 276, 1939; with portrait). It is now learned, with regret, that he died shortly afterwards, so the following additional notes may interest his numerous friends and colleagues all over the world.

Frantǐ̌ek Vejdovský was born at Kourim (Bohemia) on October 24, 1849. After passing through the Latin School, he matriculated in the philosophical faculty (natural sciences) of the Charles University of Prague, and took his doctor's degree in 1876. In the same year he became assistant to Prof. A. Fric at the Zoological Institute. Next year (1877) he was appointed lecturer in zoology at the College of Technology (Prague). In 1879 he held the post of lecturer in zoology and comparative anatorny in the University, becoming extraordinary professor in 1884. In 1892 he was elected professor of zoology, comparative anatomy, and embryology, and thereafter continued to direct the Czech Zoological Institute until 1921, when he retired as professor emeritus. His period of office covered, therefore, the rebuilding and reorganization of the Institute, and the War of 1914-18. In addition, he was dean of the philosophical faculty in 1895-6, and Rector Magnificus of the Charles Univer- sity during 1912-13. For many years he was president of the Royal Society of Sciences of Bohemia, and remained honorary president of the Zoological Society of Czechoslovakia until the day of his death. Various other societies in France, Belgium, Poland, Russia, Jugoslavia, and the United States long ago enrolled him as a member; while England, represented by the University of Cambridge, conferred an honorary doctorate upon him on the occasion of the Darwin Celebration in 1909.

For more than half a century Vejdovsky was the revered doyen of Gzech zoologists, and by his own work and his teaching exercised an enduring influence on the development of zoology in his own country. His influence was also deeply felt abroad. Most of his own researches dealt with various groups of invertebrates (Protozoa, Porifera, Turbellaria, Annelida, Nematoda, Crustacea, etc.), and were morphological, eytological, embryological, and systematic. They cover an unusually extensive field. He was especially interested in spermatogenesis, and problems connected with the centrosome and chromosomes, but also devoted much study to freshwater hydrobiology. On these and other matters he published some ten large treatises and more than a hundred other memoirs in Czech, English, French, German, and Belgian periodicals. His most important works are the "Thierische Organismen der Brunnenwässer von "Prag", and the discovery of the remarkable crustacean Bathynella (1882); the "System und Morphologie der Oligochaeten" (1884); his classical researches on Gordius (1886 and onwards); "Zrání, oplození a rýhování vajíčka" [Maturation, fertilization and cleavage of the ovum] 1886 ; "Entwicklungsgeschichtliche Untersuchungen" (1888-93); "Neue Untersuchungen über die Reifung und Befruchtung" (1907); "Zum Problem der Vererbungsträger (1912); and his final work (in English) entitled "Structure and Development of the 'Living Matter'" (1926-27).

This last book embodies Vejdovský's ultimate conclusions and opinions on many problems of cytology-on spermatogenesis, reduction, the structure of chromosomes, eytoplasmic inclusions, the origin of the centrosome, and the organization and genetic continuity of cell-constituents generally. It is a big volume of 360 pages with 24 double plates (containing 579 figures admirably drawn by his own hand), and is a notable achievement for a man nearing his eightieth birthday. Much of this work was done during the War of 1914-18, under extreme difficulties, and its completion and publication-in a foreign languageafford convincing evidence of its author's industry and erudition.

Vejdovský died at Prague on December 4, 1939. Shortly before his death, his ninetieth birthday was celebrated by the publication of a Festschrift to which many of his colleagues, friends, and pupils contributed. It is an octavo of over six hundred pages, with a portrait and full bibliography of his publications, and entitled "Sbornflk prací vydaný k 90 . narozeninám Prof. Dr. Františka Vejdovského Královskou českou společností nauk a Cs. zoologickou společností v Praze [Collection of works edited for the 90th birthday of Prof. F. Vejdovsky by the Royal Czech Society of Science and the Czechoslovak Zoological Society of Prague]". It forms vols. VI-VII of the Proceedings [Vðstnik] of the Zoological Society for the year 1938-39 (Prague, 1939). As yet only one copy of this volume--surely unique in the annals of zoology-appears to have reached England. 